\title{
Ethnobotanical Research of Plants Used in Traditional Medicine for The Treatment of Epilepsy in Southern Mozambique
}

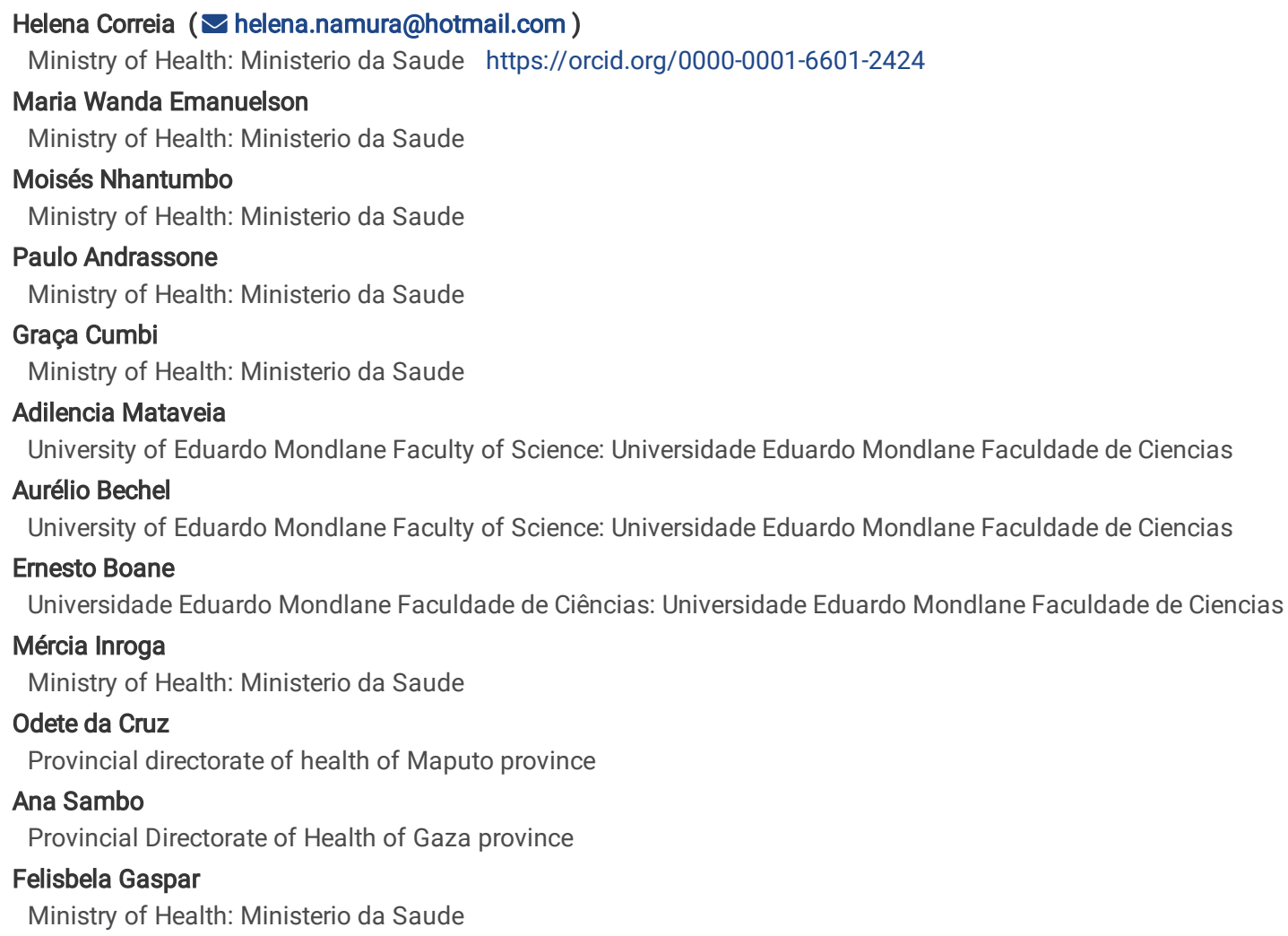

Keywords: Medicinal plants, Epilepsy, Southern Mozambique.

Posted Date: August 31st, 2021

DOI: https://doi.org/10.21203/rs.3.rs-840004/v1

License: (c) (i) This work is licensed under a Creative Commons Attribution 4.0 International License. Read Full License 


\section{Abstract \\ Background}

Epilepsy is a chronic brain disease that affects about 50 million people worldwide, mainly in developing countries. It is treated with anticonvulsant drugs, but in some cases, conventional anticonvulsants have not been effective, leading patients to turn to alternative herbal treatments. The study aimed to identify plants used in traditional medicine for the treatment of epilepsy in southern Mozambique, record the parts used, the method of preparation as well as the mode of administration.

\section{Methodology:}

The study was conducted between April to June 2019. 53 Traditional Medicine Practitioners were interviewed using a semi-structured questionnaire. The data was analyzed by calculating the Percentage of Citation (\%FC) and Informant Factor Consensus (IFC).

\section{Results}

A total of 32 medicinal plants belonging to 18 botanical families were identified for the treatment of epilepsy in the southern part of Mozambique. The species, Hugonia orientalis Engl (22.64\%), Maclura africana Bur (16.98\%), Strychnos spinosa Lam (13.21\%), Terminalia sericea Bruch ex DC (13.21\%) and Manilkara mochisia (Bark) Dubard (11.32\%) were the most cited. The families Annonaceae and Menispermaceae (4 species) were the most representative in number of species. The root was the most commonly used plant part (54.2\%), the frequently used preparation mode was decoction (71\%), and administration of the remedies was often by oral route.

\section{Conclusion}

Medicinal plants still play an important role in primary health care in the study area. However there is a need to develop pharmacological studies based on these plants to understand the mechanism of action of the bioactive compounds and for the future development of new and more effective anticonvulsant drugs

\section{Introduction}

Epilepsy is a chronic non-communicable brain disease that affects about 50 million people worldwide [1]. The disease is characterized by recurrent seizures that may be partial when they involve one part of the body or generalized when they involve the whole body [1].

In Africa, epilepsy is estimated to affect about $80 \%$ of the population [1]. In Mozambique, epilepsy is the leading cause of mental health consultations, accounting for $48 \%$ of all mental health consultations [2].

Most cases of epilepsy are idiopathic, although in some cases they result from brain injury, stroke, brain tumor, genetic mutations, severe malaria and drug abuse [3].

Epilepsy can be controlled by anticonvulsant drugs such as phenytoin, carbamazepine and phenobarbital [4]. It is estimated that 70\% of patients can control their seizures, on the other hand $30 \%$ of patients with focal lesions need other ways to ameliorate their seizures [5-7]. This fact leads patients to turn to alternative herbal treatments [5].

The World Health Organization estimates that $80 \%$ of the world population relies mainly on traditional medicine for primary health care [8]. In Mozambique, about $60 \%$ of the population relies on traditional medicine for primary health care [9].

In different studies of anticonvulsant activity, several plants have shown promising results. Among them are: Flueggea virosa, Psorospermum senegalensis [13], Bridelia micrantha, Crotonm acrostachyus [14].

There is growing interest in the use of natural sources as an alternative for developing new anticonvulsant drugs that are more effective than currently available anticonvulsants [10-12].

The present study was carried out with the aim of identifying the medicinal plants used in traditional medicine for the treatment of epilepsy, recording the parts used, the method of preparation, as well as the method of administration.

\section{Material And Methods}

\subsection{Study area}

The study was conducted in the southern part of Mozambique, in the districts of Matutuine and Magude (Maputo Province), Mabalane (Gaza Province) and Funhalouro, Inharrime (Inhambane Province). These provinces were selected taking into account that in the southern part of the country, there is some 
traditional knowledge for the treatment and prevention of various plant-based diseases, including epilepsy [15]. Therefore, the provinces serve as the main source of medicinal plant collection by many traditional medicine practitioners in the southern part of Mozambique [15].

Matutuíne district is located in the extreme south of Maputo Province. It covers an area of approximately $5,387 \mathrm{~km}^{2}$ and has an estimated population of 52,703 inhabitants [16]. Magude district is located in the north of Maputo Province. It has an area of 6,960 km² and an estimated population of 54,225 inhabitants [16]. Mabalane district is located in the center of Gaza Province. Its area is $8,922 \mathrm{Km}^{2}$ with an estimated population of about 36,121 inhabitants [16]. Inharrime district is located in the southern part of Inhambane Province with an area of $2748 \mathrm{Km}^{2}$ and an estimated population of about 116285 inhabitants [16]. The district of Funhalouro is located in the central part of Inhambane Province with a surface area of $13617 \mathrm{Km}^{2}$ and an estimated population of about 44320 inhabitants [16]. (shown in Fig. 1).

\subsection{Data collection and plant identification}

The study was carried out between April to June 2019. A semi-structured questionnaire was developed and administered individually to each Traditional Medicine Practitioner (TMP) according to their local language and with support from a local translator. This questionnaire aimed to obtain sociodemographic information such as age, years of experience, source of knowledge of traditional treatment and the plants used for the treatment of epilepsy. Plants were mentioned by their vernacular names and the parts used methods of preparation as well as the mode of administration were identified.

Plants were collected during fieldwork with the help of Traditional Medicine practitioners. Voucher species were deposited in the LMU herbarium at Eduardo Mondlane University, where they were scientifically identified using dichotomous keys and herborized plant samples by comparison. The scientific names were confirmed in the plant list (www.theplantlist.org). Accessed 27 May 2021.

\subsection{Data analysis}

Data were stored in a database and analyzed in the statistical program Microsoft excel (version 2007). The percentage of citation (\%FC) and Informant Consensus Factor (ICF) were calculated.

The Citation Percentage (\%FC) was calculated by dividing the citation frequency (CF) by the total number of informants in the survey (N) [17]:

$$
\% \mathrm{FC}=\frac{\mathrm{FC}}{\mathrm{N}} \times 100(0<\mathrm{FC}<100)
$$

FC values range from 0 , when nobody mentions the plant as useful for epilepsy treatment, and 100 in the unlikely case where all informants mention the use of the species [17].

The Informant Factor Consensus (IFC) was calculated following the formula [18]:

$$
\mathrm{IFC}=\frac{\mathrm{N}_{\mathrm{ur}}-\mathrm{N}_{\mathrm{t}}}{\mathrm{N}_{\mathrm{ur}}-1}(0<\mathrm{IFC}<1)
$$

Where $\mathrm{N}_{\mathrm{ur}}$ refers to the number of reported uses in each disease category and $\mathrm{N}_{\mathrm{t}}$ the number of species used [18].

\section{Results}

\subsection{Socio-demographic information of the interviewees}

A total of 53 Traditional Medicine Practitioners (TMP) were interviewed. Of these 43 were female (81.1\%) and 10 male (18.9\%). In terms of provenance, 14 were from Maputo Province, 29 from Gaza and 10 from Inhambane. Age ranged from 30-84 years, of which 52.8\% were between 50-69 years, which corresponded to the majority of the interviewees, followed by those aged 30-49 years (37.7\%) and lastly, those aged 70 years or more (7.5\%). The majority of the interviewees (81.1\%) had 10-20 years of experience as PMT, followed by those who had less than 10 years (13.2\%) and $30-40$ years (7.5\%).

Regarding their training, $69.8 \%$ of the practitioners were trained at home by another experienced practitioner (Mbava) affiliated to the Traditional Healers Association of Mozambique (THAMO) and 24.5\% learned their practices through the manifestations of familiar spirits that showed them the plants through visions or dreams (Table 1). 
Table 1

Socio-demographic information of the interviewees

\begin{tabular}{|lll|}
\hline Variable & N & (\%) \\
\hline Gender & & \\
Female & 43 & 81.1 \\
\hline Male & 10 & 18.9 \\
\hline Age (years) & & \\
\hline $30-49$ & 20 & 37.7 \\
\hline $50-69$ & 28 & 52.8 \\
\hline$\geq 70$ & 4 & 7.5 \\
\hline Years of experience & & \\
\hline$<10$ & 7 & 13.2 \\
\hline $10-29$ & 43 & 81.1 \\
\hline $30-40$ & 4 & 7.5 \\
\hline Knowledge source & & \\
\hline Did training & 37 & 69.8 \\
\hline Herbalist & 3 & 5.7 \\
\hline Familiar spirits & 13 & 24.5 \\
\hline Province & & \\
\hline Maputo & 14 & 26.4 \\
\hline Gaza & 54.7 \\
\hline Inhambane & 18.9 \\
\hline Source: Data from survey participants \\
\hline
\end{tabular}

\subsection{Traditional perception of epilepsy}

Regarding the traditional etiology of epilepsy, most of the TMP (80\%) stated that epilepsy is a disease caused by spell (action of evil spirits), on the other hand, some (20\%) stated that the disease is caused by "Nhocane" which means snake or worm. This worm lives inside the belly of the child in the area below the navel. There are 2 types, "Nhoca ley tsongo" which means small female snake and "Nhoca ley Kulo" which means male or large snake. The latter is considered to be the main cause of epilepsy in children and adults. This worm comes from the mother's womb, being the place where the child contracts it during gestation. The main clinical manifestations of the disease during an epileptic seizure were: falling down, urinating, rolling eyes, foaming at the mouth, rigidity of the upper and lower limbs, trembling, teeth grinding, stomach pains, headaches and frights.

\subsection{Plants used to treat epilepsy}

A total of 32 medicinal plants belonging to 18 botanical families were identified for the treatment of epilepsy in southern Mozambique. Table 2 contains information of all identified species, the family, vernacular name, voucher number, the growth form of the plants, the parts used, mode of preparation, mode of administration, other traditional uses reported and the percentage of citation for each species. Among the identified plants, the species Hugonia orientalis Engl. (22.64\%), Maclura africana Bur. (16.98\%), Strychnos spinosa Lam. (13.21\%), Terminalia sericea Bruch. ex DC (13.21\%) and Manilkara mochisia (Bark.) Dubard (11.32\%) showed highest citation percentage (\%FC) (Table 2). 
Table 2

List of plants mentioned by practitioners of traditional medicine used for treating epilepsy in southern Mozambique

\begin{tabular}{|c|c|c|c|c|c|c|c|c|c|}
\hline Scientific name & $\begin{array}{l}\text { Vernacular } \\
\text { name }\end{array}$ & Family & $\begin{array}{l}\text { Voucher } \\
\text { number }\end{array}$ & $\begin{array}{l}\text { Growth } \\
\text { form }\end{array}$ & $\begin{array}{l}\text { Used } \\
\text { part }\end{array}$ & $\begin{array}{l}\text { Mode of } \\
\text { preparation }\end{array}$ & $\begin{array}{l}\text { Mode of } \\
\text { administration }\end{array}$ & Other uses & $\% F C$ \\
\hline $\begin{array}{l}\text { Albertisia } \\
\text { delagoensis } \\
\text { (N.E.Br) Forman }\end{array}$ & $\begin{array}{l}\text { Kodhodho, } \\
\text { Cododo }\end{array}$ & Menispermaceae & AB169 & Shrub & Roots & Decoction & Oral & $\begin{array}{l}\text { Moon } \\
\text { sickness }\end{array}$ & 3.77 \\
\hline $\begin{array}{l}\text { Annona } \\
\text { senegalensis } \\
\text { Pers. }\end{array}$ & Rofwa wa kulafi & Annonaceae & AB183 & Shurb & Roots & Decoction & Oral & $\begin{array}{l}\text { Colics and } \\
\text { asthma }\end{array}$ & 1.89 \\
\hline $\begin{array}{l}\text { Ansellia africana } \\
\text { Lindl. }\end{array}$ & Ngonhama & Orchidaceae & AB181 & Herb & $\begin{array}{l}\text { Roots } \\
\text { and } \\
\text { leaves }\end{array}$ & Decocção & Oral & Worms & 7.55 \\
\hline $\begin{array}{l}\text { Artabotrys } \\
\text { brachypetalus } \\
\text { Benth }\end{array}$ & Ntita & Annonaceae & AB174 & Shurb & Roots & Decoction & Oral & $\begin{array}{l}\text { Moon } \\
\text { sickness }\end{array}$ & 9.43 \\
\hline $\begin{array}{l}\text { Catunaregam } \\
\text { spinosa (Thunb.) } \\
\text { Tirveng. }\end{array}$ & $\begin{array}{l}\text { Xibamarole, } \\
\text { Xiba marok }\end{array}$ & Rubiaceae & AB164 & Shurb & Roots & Deccoction & $\begin{array}{l}\text { Oral and } \\
\text { massage }\end{array}$ & $\begin{array}{l}\text { Moon } \\
\text { sickness }\end{array}$ & 5.66 \\
\hline $\begin{array}{l}\text { Cissampelos } \\
\text { mucronata A. } \\
\text { Rich. }\end{array}$ & Nhocanhocane & Menispermaceae & AB184 & Climber & Roots & Decotion & Oral & Back pain & 3.77 \\
\hline $\begin{array}{l}\text { Cladostemon } \\
\text { kirkii (Oliv.) Pax \& } \\
\text { Gilg. }\end{array}$ & Mawocane & Caparraceae & AB178 & Tree & Leaves & Maceration & Oral & Cough & 1.89 \\
\hline $\begin{array}{l}\text { Cocculus hirsutus } \\
\text { (L.) W.Theob. }\end{array}$ & Mulha nhoca & Menispermaceae & AB182 & Climber & $\begin{array}{l}\text { Roots } \\
\text { and } \\
\text { leaves }\end{array}$ & Decoction & Oral & Cólicas & 1.89 \\
\hline $\begin{array}{l}\text { Cucumis } \\
\text { metuliferus E.Mey. } \\
\text { ex Naudin }\end{array}$ & Dema & Curcubitaceae & AB185 & Climber & $\begin{array}{l}\text { Roots, } \\
\text { leaves } \\
\text { and } \\
\text { fruit }\end{array}$ & Decocção & Oral & $\begin{array}{l}\text { Back pain } \\
\text { and } \\
\text { Bilharziosis }\end{array}$ & 5.66 \\
\hline $\begin{array}{l}\text { Cyphostemma } \\
\text { congestum } \\
\text { (Baker) Desc. ex } \\
\text { Wild \& } \\
\text { R.B.Drumm. }\end{array}$ & Nhamuntana & Vitaceae & AB161 & Climber & $\begin{array}{l}\text { Roots } \\
\text { and } \\
\text { leaves }\end{array}$ & Decoction & Oral & Fever & 1.89 \\
\hline $\begin{array}{l}\text { Garcinia } \\
\text { livingstonei T. } \\
\text { Anderson. }\end{array}$ & Mahimbe & Clusiaceae & AB186 & Tree & $\begin{array}{l}\text { Roots } \\
\text { and } \\
\text { leaves }\end{array}$ & Decoction & Oral & Asthma & 1.89 \\
\hline $\begin{array}{l}\text { Gymnanthemum } \\
\text { coloratum (Willd.) } \\
\text { H.Rob. \& B.Kahn }\end{array}$ & Phalha Kufa & Asteraceae & AB177 & Shurb & $\begin{array}{l}\text { Roots } \\
\text { and } \\
\text { leaves }\end{array}$ & Decoction & Oral & $\begin{array}{l}\text { Cough and } \\
\text { asthma }\end{array}$ & 7.55 \\
\hline $\begin{array}{l}\text { Grewia caffra } \\
\text { Meisn. }\end{array}$ & Nhocana ukulo & Malvaceae & AB179 & Shurb & $\begin{array}{l}\text { Roots } \\
\text { and } \\
\text { leaves }\end{array}$ & Decoction & Oral & Colics & 5.66 \\
\hline $\begin{array}{l}\text { Helichrysum } \\
\text { kraussii Sch.-Bip }\end{array}$ & Chiringuate & Asteraceae & AB187 & Shurb & Roots & Decoction & Oral & $\begin{array}{l}\text { Moon } \\
\text { sickness }\end{array}$ & 1.89 \\
\hline $\begin{array}{l}\text { Holarrhena } \\
\text { pubescens Wall. } \\
\text { Ex G.Don }\end{array}$ & Chiritse & Apocynaceae & AB171 & Tree & Roots & Decoction & Oral & $\begin{array}{l}\text { Moon } \\
\text { sickness }\end{array}$ & 1.89 \\
\hline $\begin{array}{l}\text { Huernia kirkii N.E. } \\
\text { Br. }\end{array}$ & Lhakuzi & Apocynaceae & AB188 & Herb & $\begin{array}{l}\text { Roots } \\
\text { and } \\
\text { stem }\end{array}$ & Maceration & Oral & Worms & 1.89 \\
\hline $\begin{array}{l}\text { Hugonia orientalis } \\
\text { Engl. }\end{array}$ & kongolotamunte & Linaceae & AB162 & Shurb & $\begin{array}{l}\text { Roots, } \\
\text { bark } \\
\text { and } \\
\text { leaves }\end{array}$ & Decoction & Oral & $\begin{array}{l}\text { Moon } \\
\text { sickness }\end{array}$ & 22.64 \\
\hline $\begin{array}{l}\text { Ipomoea obscura } \\
\text { (L.) Ker Gawl. }\end{array}$ & Sungucate & Convulvulaceae & AB165 & Herb & Roots & Decoction & Oral & Moon sicknes & 1.89 \\
\hline $\begin{array}{l}\text { Maclura africana } \\
\text { (Bureau) Corner }\end{array}$ & Mpumbolo & Moraceae & $A B 170$ & Shurb & Roots & Decoction & Oral & Asthma & 16.98 \\
\hline $\begin{array}{l}\text { Manilkara } \\
\text { mochisia (Bark.) } \\
\text { Dubard }\end{array}$ & $\begin{array}{l}\text { Nwambo, } \\
\text { Muhambo }\end{array}$ & Sapotaceae & AB168 & Tree & Roots & $\begin{array}{l}\text { Decoction } \\
\text { and } \\
\text { infusion }\end{array}$ & Oral & $\begin{array}{l}\text { Worm and } \\
\text { colics }\end{array}$ & 11.32 \\
\hline
\end{tabular}




\begin{tabular}{|c|c|c|c|c|c|c|c|c|c|}
\hline Scientific name & $\begin{array}{l}\text { Vernacular } \\
\text { name }\end{array}$ & Family & $\begin{array}{l}\text { Voucher } \\
\text { number }\end{array}$ & $\begin{array}{l}\text { Growth } \\
\text { form }\end{array}$ & $\begin{array}{l}\text { Used } \\
\text { part }\end{array}$ & $\begin{array}{l}\text { Mode of } \\
\text { preparation }\end{array}$ & $\begin{array}{l}\text { Mode of } \\
\text { administration }\end{array}$ & Other uses & $\% F C$ \\
\hline $\begin{array}{l}\text { Rhoicissus revoilii } \\
\text { Planch. }\end{array}$ & Nlalhapwane & Vitaceae & AB167 & Shurb & $\begin{array}{l}\text { Roots } \\
\text { and } \\
\text { leaves }\end{array}$ & Maceration & Oral and bath & $\begin{array}{l}\text { Carbúnculo, } \\
\text { hérpes }\end{array}$ & 5.66 \\
\hline $\begin{array}{l}\text { Senna } \\
\text { occidentalis (L.) } \\
\text { Link }\end{array}$ & $\begin{array}{l}\text { Nhocana } \\
\text { utsongo }\end{array}$ & Fabaceae & AB189 & Shurb & $\begin{array}{l}\text { Roots } \\
\text { and } \\
\text { leaves }\end{array}$ & $\begin{array}{l}\text { Decoction } \\
\text { and } \\
\text { maceration }\end{array}$ & Oral and bath & $\begin{array}{l}\text { Doença da } \\
\text { lua }\end{array}$ & 5.66 \\
\hline $\begin{array}{l}\text { Senna petersiana } \\
\text { (Bolle) Lock }\end{array}$ & $\begin{array}{l}\text { Nembenembe, } \\
\text { Nhadzente }\end{array}$ & Fabaceae & AB190 & Shurb & $\begin{array}{l}\text { Roots } \\
\text { and } \\
\text { leaves }\end{array}$ & $\begin{array}{l}\text { Decoction, } \\
\text { maceration } \\
\text { and } \\
\text { infusion }\end{array}$ & Oral & $\begin{array}{l}\text { Worm and } \\
\text { bilharziosis }\end{array}$ & 9.43 \\
\hline $\begin{array}{l}\text { Strychnos } \\
\text { decussata } \\
\text { (Pappe) Gild }\end{array}$ & Tambaculota & Loganiaceae & AB159 & Tree & $\begin{array}{l}\text { Roots } \\
\text { and } \\
\text { leaves }\end{array}$ & Decoction & Oral & Back pain & 5.66 \\
\hline $\begin{array}{l}\text { Strychnos } \\
\text { madagascariensis } \\
\text { Poir. }\end{array}$ & Macuacua & Loganiaceae & AB175 & Tree & $\begin{array}{l}\text { Roots } \\
\text { and } \\
\text { leaves }\end{array}$ & Decoction & Oral & Colics & 9.43 \\
\hline $\begin{array}{l}\text { Strychnos spinosa } \\
\text { Lam. }\end{array}$ & Nsala & Loganiaceae & AB173 & Tree & $\begin{array}{l}\text { Roots } \\
\text { and } \\
\text { leaves }\end{array}$ & Decoction & Oral & Stomachache & 13.21 \\
\hline $\begin{array}{l}\text { Terminalia sericea } \\
\text { Bruch. ex DC. }\end{array}$ & Konola & Combretaceae & AB158 & Tree & $\begin{array}{l}\text { Roots, } \\
\text { bark } \\
\text { and } \\
\text { leaves }\end{array}$ & $\begin{array}{l}\text { Decoction } \\
\text { and } \\
\text { maceration }\end{array}$ & Oral & $\begin{array}{l}\text { Diarrhoea, } \\
\text { bilharziosis, } \\
\text { haemorrhoid } \\
\text { and colics }\end{array}$ & 13.21 \\
\hline $\begin{array}{l}\text { Tiliacora funifera } \\
\text { (Miers) Oliv. }\end{array}$ & Xiwizila & Menispermaceae & AB180 & Climber & $\begin{array}{l}\text { Roots } \\
\text { and } \\
\text { leaves }\end{array}$ & $\begin{array}{l}\text { Decoction } \\
\text { and } \\
\text { maceration }\end{array}$ & Oral & Bilharziosis & 3.77 \\
\hline $\begin{array}{l}\text { Uvaria caffra E. } \\
\text { Mey. ex Sond. }\end{array}$ & Tsovatsova & Annonaceae & AB160 & Shurb & $\begin{array}{l}\text { Roots } \\
\text { and } \\
\text { leaves }\end{array}$ & $\begin{array}{l}\text { Decoction } \\
\text { and } \\
\text { maceration }\end{array}$ & Oral & Back pain & 7.55 \\
\hline $\begin{array}{l}\text { Uvaria lucida } \\
\text { (N.E.Br.) Verdc. }\end{array}$ & Muvava & Annonaceae & AB166 & Shurb & $\begin{array}{l}\text { Roots } \\
\text { and } \\
\text { leaves }\end{array}$ & Decoction & Oral & Asthma & 3.77 \\
\hline $\begin{array}{l}\text { Vangueria } \\
\text { infausta Burch. }\end{array}$ & Pfilwa & Rubiaceae & AB176 & Shurb & $\begin{array}{l}\text { Roots } \\
\text { and } \\
\text { leaves }\end{array}$ & Decoction & Oral & Diarrhoea & 9.43 \\
\hline $\begin{array}{l}\text { Xeroderris } \\
\text { stuhlmannii } \\
\text { (Taub.) Mendonça } \\
\text { e Sousa }\end{array}$ & Ndzungua & Fabaceae & AB163 & Tree & $\begin{array}{l}\text { Roots, } \\
\text { bark } \\
\text { and } \\
\text { leaves }\end{array}$ & $\begin{array}{l}\text { Decoction } \\
\text { anad } \\
\text { maceration }\end{array}$ & Oral & $\begin{array}{l}\text { Carbuncle } \\
\text { and herpes }\end{array}$ & 5.66 \\
\hline
\end{tabular}

Source: Information from ethnobotanical survey of the study

The most representative botanical families in number of species were Annonaceae and Menispermaceae with 4 species followed by Fabaceae and Loganiaceae with 3 species. The other families were represented by 1 or 2 species (shown in Fig. 2).

Most plants used for epilepsy treatment were shrubs (46.9\%), followed by trees (28.1\%), climbers (15.6\%) and herbs (9.4\%). The remedies are mainly administered orally. Apart from this mode, external administration of the remedies was also mentioned in the form of bath ( 2 species) and body massage (1 species) (Table 2).

With regard to other reported uses, Terminalia sericea was the only species referred for treatment of various diseases such as epilepsy, diarrhea, bilharzia, colic and hemorrhoids.

\subsection{Plant parts used, methods of preparation and level of Informant Factor Consensus (IFC)}

The plant parts used by TMP for the treatment of epilepsy were the roots (54.2\%), leaves (37.3\%), bark (3.4\%), branches and fruit (1.7\%) shown in Fig. 3. The commonly used mode of preparation was decoction (71\%), followed by maceration (24\%) and infusion (5\%).

The Table 3 contains the informant factor consensus values (IFC) for different categories of diseases. Diseases of the digestive system (diarrhea, worms) showed a high IFC value of 0.83 ( 2 species and 7 reported uses). This indicates that there was a consensus in the use of the plants cited for the treatment of these diseases although they showed lower number of plants and reported uses. The category of nervous system diseases, which includes epilepsy showed an IFC of 0.52 (33 species and 68 reported uses). 
Table 3

Informant consensus values (IFC) of different disease categories

\begin{tabular}{|c|c|c|c|c|}
\hline Disease category ${ }^{*}$ & Diseases reported & $\mathrm{N}_{\mathrm{t}}$ & $\mathrm{N}_{\mathrm{ur}}$ & IFC \\
\hline Certain infectious or parasitic diseases & Bilharziosis, Carbuncle and Haemorrhoid & 8 & 33 & 0.78 \\
\hline Nervous system diseases & Epilepsy & 33 & 68 & 0.52 \\
\hline Respiratory system diseases & Asthma and cough & 7 & 12 & 0.45 \\
\hline Digestive system diseases & Diarrhoea and worms & 2 & 7 & 0.83 \\
\hline Diseases of the musculoskeletal system or connective tissue & Back pain & 5 & 19 & 0.78 \\
\hline Genitourinary Diseases & Colics & 6 & 27 & 0.81 \\
\hline Symptoms, signs or clinical findings, not elsewhere classified & Moon sicknessand stomachache and fever & 10 & 16 & 0.40 \\
\hline Skin diseases & Herpes & 2 & 4 & 0.67 \\
\hline
\end{tabular}

\section{Discussion}

In the present study, most of the TMP interviewed were female (81.1\%) compared to male (18.9\%). This is due to the fact that women are responsible for the primary health care of their families, particularly children [19]. Most of the TMP were aged between 50-69 years. Generally older people use more traditional remedies than young people and this traditional knowledge tends to disappear in the young layer [20]. This fact may be coupled with lack of interest in traditional practices, on the part of young people.

Traditional perceptions regarding the etiology of epilepsy are common in different regions of Africa. For example, in Tanzania, Congo and Guinea-Bissau most traditional doctors also believed that epilepsy is caused by witchcraft [21-23]. Therefore, health programs should be developed in rural communities to clarify the causes of epilepsy in order to reduce or eliminate the existing myths and taboos surrounding the disease.

The families Annonaceae and Menispermaceae were most representative in number of species (4 species). According to Auditeau et al [24], species belonging to these families are characterized for presenting anticonvulsant properties.

The plants Hugonia orientalis, Maclura africana, Strychnos spinosa, Terminalia sericea and Manilkara mochisia were the most cited for the treatment of epilepsy in the study area. On the other hand, there are no published studies regarding the use of these plants for the treatment of epilepsy. However, these plants are frequently used in traditional medicine for the treatment of different ailments in Mozambique and other countries [25-28].

In Mozambique Hugonia orientalis is commonly used in traditional medicine for the treatment of Malaria, diarrhea and wounds [25, 29]. Maclura africana is used in traditional medicine for treatment of respiratory diseases and helminthiasis $[25,30]$. Strychnos spinosa is used for the treatment of helminthiasis, venereal diseases, hernia, snake bite, earache [25, 31]. In Madagascar it is used as anti-dandruff, and anti-flu [27].

Dichloromethane extracts of Strychnos spinosa leaves possess efficient anti-plasmodial and anti-trypanosomal activity [28, 32]. Terminalia sericea is commonly used in Mozambique for treatment of, dysentery, helminthiasis, hemorrhoids, colic and female infertility [9, 25, 31]. In South Africa it is often used to treat diarrhea [26]. Terminalia sericea also exhibits efficient anti-oxidant activity, activity and anti-HIV-through inhibition of the enzyme alphaglucosidase [33-34]. Extracts of Terminalia sericea root possess efficient anti-mycobacterial activity due to the presence of ellagitannins, ellagic acid and stilbene glycoside [35].

\subsection{Parts of the plant used, method of preparation, administration and Informant Factor consensus (IFC)}

The root (54.2\%) was the part of the plant most used for the treatment of epilepsy in southern Mozambique. Similarly, in Tanzania, roots are frequently used for the treatment of epilepsy [22]. The wide use of the roots by practitioners of traditional medicine is based on the perception that the therapeutic power is most concentrated in this part of the plant [36].

The commonly used mode of preparation is decoction (71\%). Moshi et al [22] reported that decoction is also frequently used for treatment of epilepsy in Tanzania. This is because it is believed that active ingredients are easily extracted by boiling the plants, coupled with this, traditional medicine practitioners do not have much conventional knowledge about the ways of extracting active ingredients in plants [37].

The administration of the remedies was mainly by oral route. The preference of the method by traditional medicine practitioners may be due to the fact that the remedy administered orally is easily absorbed by the body [36]. Apart from oral administration, administration by means of bath and massage has been mentioned. This method is also common in India, where the administration of the remedies is through baths [38]. This method is usually coupled with traditional beliefs for the removal of evil spirits and purification of the body. 
With respect to Informant Factor consensus (IFC), the highest level of consensus was observed in the category of digestive system diseases (diarrhea, roundworms) (0.83), despite the category containing the lowest number of species and reported uses. Similar results have been reported in several studies where the highest level of IFC was observed in the category with the lowest number of species and reported uses [17, 29, 39]. The category of nervous system disorders, which includes epilepsy showed an IFC of 0.52 . This reinforces the fact that different types of plants were cited by traditional medicine practitioners for the treatment of epilepsy [29].

\subsection{Anticonvulsant activity}

Of the plants used for treatment of epilepsy in southern Mozambique, only two (2) species, namely: Annona senegalensis Pers and Senna occidentalis ( $\mathrm{L}$ ) Link, showed anticonvulsant activity [40-45]. No published studies on the anticonvulsant activity of the remaining species were found (Table 4).

Table 4

Anticonvulsant activity of some plants used in traditional medicine to treat epilepsy in southern Mozambique.

\begin{tabular}{|c|c|c|c|c|c|c|}
\hline $\begin{array}{l}\text { Cientific } \\
\text { name }\end{array}$ & $\begin{array}{l}\text { Analised } \\
\text { part }\end{array}$ & $\begin{array}{l}\text { Exctrat/ } \\
\text { compounds } \\
\text { used }\end{array}$ & $\begin{array}{l}\text { Experimental } \\
\text { model of seizure }\end{array}$ & $\begin{array}{l}\text { Experimental } \\
\text { animals }\end{array}$ & Results & Reference \\
\hline \multirow[t]{5}{*}{$\begin{array}{l}\text { Annona } \\
\text { senegalensis } \\
\text { Pers. }\end{array}$} & $\begin{array}{l}\text { Stem } \\
\text { bark }\end{array}$ & $\begin{array}{l}\text { Methanol, n- } \\
\text { hexane } \\
\text { fraction, ethyl } \\
\text { acetate } \\
\text { fraction and } \\
\text { aqueous } \\
\text { fraction }\end{array}$ & $\begin{array}{l}\text { Pentylenetetrazole } \\
\text { (PTZ) and } \\
\text { pilocarpine }\end{array}$ & $\begin{array}{l}\text { Male mice } \\
(25-30 \mathrm{~g}) \text { and } \\
\text { male rats } \\
(200-250 \mathrm{~g})\end{array}$ & $\begin{array}{l}\text { Extracts and fractions were not significant in } \\
\text { reducing the latency of first seizures induced by } \\
\text { pentylenetetrazole or pirocarpine. Treatment with } \\
\text { methanolic extracts and aqueous fraction } \\
(400 \mathrm{mg} / \mathrm{kg}) \text { were significant }(p<0.05) \text { in protecting } \\
\text { against pentylenetetrazole or pyrocarpine induced } \\
\text { seizures. }\end{array}$ & $\begin{array}{l}\text { (Almamy, } \\
\text { et al., } \\
2012 \text { ) }\end{array}$ \\
\hline & Roots & Aqueous & $\begin{array}{l}\text { Pentylenetetrazole } \\
\text { (PTZ) and } \\
\text { eletroshock }\end{array}$ & $\begin{array}{l}\text { Adult albino } \\
\text { mice }(20- \\
35 \mathrm{~g})\end{array}$ & $\begin{array}{l}\text { Ethanolic extracts were effective at high doses (LD50 } \\
954.99 \pm 2.86 \mathrm{mg} / \mathrm{kg} \text { ) in protecting against PTZ- } \\
\text { induced seizures in rats, preventing elecrtochoke, and } \\
\text { were shown to be more effective against generalized } \\
\text { than partial seizures. }\end{array}$ & $\begin{array}{l}\text { (lgwe \& } \\
\text { Nwobodo } \\
\text { 2014) }\end{array}$ \\
\hline & $\begin{array}{l}\text { Root } \\
\text { bark }\end{array}$ & $\begin{array}{l}\text { Kaurenoic } \\
\text { acid (kaur-16- } \\
\text { en-19-oic } \\
\text { acid) and } \\
\text { ethyl acetate } \\
\text { fraction }\end{array}$ & $\begin{array}{l}\text { Pentylenetetrazole } \\
\text { (PTZ) }\end{array}$ & $\begin{array}{l}\text { Adult albino } \\
\text { rats }(18-30 \mathrm{~g}) \\
\text { and mice of } \\
(180-250 \mathrm{~g})\end{array}$ & $\begin{array}{l}\text { The ethyl acetate fraction and kaur- } 16 \text {-en-19-oic acid } \\
\text { significantly }(p<0.05) \text { dose-dependently delayed the } \\
\text { onset of myoclonic spasms and tonic-clonic phases } \\
\text { of PTZ-induced seizures and maximal electroshock } \\
\text { seizures. }\end{array}$ & $\begin{array}{l}\text { (Okoye, et } \\
\text { al., 2013) }\end{array}$ \\
\hline & $\begin{array}{l}\text { Root } \\
\text { bark }\end{array}$ & Methanol & $\begin{array}{l}\text { Pentylenetetrazole } \\
\text { (PTZ) }\end{array}$ & $\begin{array}{l}\text { Adult albino } \\
\text { mice }(18- \\
30 \mathrm{~g})\end{array}$ & $\begin{array}{l}\text { The extract }(200,400,800 \mathrm{mg} / \mathrm{kg}) \text { exhibited } \\
\text { significantly }(\mathrm{p}<0.05) \text { dose-dependent delay of onset } \\
\text { of tonic and clonic phases of Pentylenetetrazole-- } \\
\text { induced seizures }(60 \mathrm{mgf} / \mathrm{kg}) \text { as well as offered } 100 \% \\
\text { protection }(200 \mathrm{mg} / \mathrm{kg}) \text { against Pentylenetetrazole- } \\
\text { induced seizures in rats. }\end{array}$ & $\begin{array}{l}\text { Okeye et } \\
\text { al., } 2010\end{array}$ \\
\hline & Folhas & $\begin{array}{l}\text { Methanol and } \\
\text { matanolic } \\
\text { fraction }\end{array}$ & $\begin{array}{l}\text { Pentylenetetrazole } \\
\text { (PTZ) }\end{array}$ & $\begin{array}{l}\text { Adult Swiss } \\
\text { albino rats } \\
(150-200 \mathrm{~g}) \\
\text { mice }(19- \\
22 \mathrm{~g})\end{array}$ & $\begin{array}{l}\text { The extracts and fractions caused significant }(p< \\
0.05) \text { inhibition of Pentylenetetrazole-induced } \\
\text { seizures. }\end{array}$ & $\begin{array}{l}\text { (Okoli et } \\
\text { al., 2010) }\end{array}$ \\
\hline $\begin{array}{l}\text { Senna } \\
\text { occidentalis } \\
\text { (L.) Link }\end{array}$ & Seeds & Ethanol & $\begin{array}{l}\text { Pentylenetetrazole } \\
\text { (PTZ) and } \\
\text { maximum } \\
\text { electroshock } \\
\text { (MES). }\end{array}$ & $\begin{array}{l}\text { Swiss albino } \\
\text { mice }(30- \\
40 \mathrm{~g}) \text {, Swiss } \\
\text { albino rats } \\
(200-250 \mathrm{~g})\end{array}$ & $\begin{array}{l}\text { The ethanolic extract of Senna occidentalis seeds at } \\
\text { a dose of } 400 \mathrm{mg} / \mathrm{kg} \text { body weight has potent } \\
\text { anticonvulsant activity. }\end{array}$ & $\begin{array}{l}\text { (Singh et } \\
\text { al., 2019) }\end{array}$ \\
\hline
\end{tabular}

The stem bark and root extracts of Annona senegalensis are efficient in inhibiting Pentylenetetrazole (PTZ)-induced seizures [40, 41]. Likewise the methanol extracts and methanol fraction of Annona senegalensis leaves caused significantly $(p<0.05)$ inhibition of Pentylenetetrazole-induced seizures [44]. The anticonvulsant activity of this plant may be due to the presence of kaurenoic acids, specifically the compound kaur-16-en-19-oic acid isolated from the root bark, as it showed efficient anticonvulsant activity by delaying the onset of myoclonic spasms and tonic-clonic phases of PTZ-induced seizures and maximal electroshock seizures [42].

The ethanoic extract of Senna occidentalis seeds at a dose of $400 \mathrm{mg} / \mathrm{kg}$ body weight possesses potent anticonvulsant activity [45]. These findings reveal that these plants may be promising for the development of new antiepileptic drugs, although they are not among the most commonly cited plants for the treatment of epilepsy in southern Mozambique.

\section{Conclusion}

Different types of plants were identified for the treatment of epilepsy in southern Mozambique. The results show that medicinal plants still play an important role in primary health care in the study area. However, there is still a need to preserve this traditional system through adequate recording and identification of indigenous species.

Some of the species like Annona senegalensis and Senna occidentalis, have been scientifically proven for anticonvulsant activity. There is need to develop studies of the anticonvulsant activity of Hugonia orientalis, Maclura africana, Strychnos spinosa, Terminalia sericea and Manilkara mochisia with a view to 
understanding the mechanisms of action of the bioactive compounds present in the plants, since they were the most cited for the treatment of epilepsy in the study area.

\section{Abbreviations}

FC

Citation frequency; IFC:Informants Factor Consensus; TMP:Traditional Medicine Practitioner, ATHM:Association of Traditional Healers of Mozambique, PTZ:Pentylenetetrazole.

\section{Declarations}

\section{Acknowledgements}

The authors thank the provincial and district health directorates, the focal points of traditional medicine, the Association of Traditional Healers of Mozambique (ATHM) of each district for their collaboration to make this work possible. The authors would also like to thank Mr. Aurélio Bechel and Ernesto Boane for their help in the scientific identification of the plants.

\section{Authors' contributions}

H.C conducted the field study, participated in field data collection, analyzed and interpreted the data, wrote the manuscript. M.W.N, F.G and G.C participated in project design, data analysis and interpretation, wrote the manuscript. P.A and M.H assisted in project development and data collection during fieldwork. A.B and E.B assisted in data collection during fieldwork, identified plants, wrote the manuscript. A.M and M.I analyzed and interpreted the data, wrote the manuscript. O.C and A.S coordinated with traditional medicine practitioners, participated in the work and fieldwork. All authors agreed with the submission of the manuscript.

\section{Funding}

This research did not receive any specific grants from funding agencies.

\section{Conflicts of interest}

The authors declare that there are no conflicts of interest.

\section{Availability of data and materials}

The data sets and/or analyzed during the current study are available from the corresponding author upon reasonable request.

\section{Ethical approval and consent of participants}

The present study was approved by the National Bioethics Committee for Health, Ministry of Health registered under number 116/CNBS/2016. Prior to conducting the interviews, informed consent was sought from all participants. All interviewees accepted in to participate in the research.

\section{Consent for publication}

Not applicable in this section

\section{Conflicts of interest}

The authors declare that there are no conflicts of interest.

\section{Information from the authors}

${ }^{1}$ National Directorate of Traditional and Alternative Medicine, Ministry of Health, Eduardo Mondlane Avenue/ Salvador Allende, Maputo, Mozambique

${ }^{2}$ Directorate of Public Health, Ministry of Health, Eduardo Mondlane Avenue/Salvador Allende, Maputo, Mozambique.

${ }^{3}$ Department of Biological Sciences, Faculty of Sciences, Eduardo Mondlane University, Julius Nyerere avenue, nr 3435, Campus Principal, Maputo, Mozambique.

${ }^{4}$ Provincial Directorate of Health of Maputo Province, Maputo, Mozambique.

${ }^{5}$ Provincial Directorate of Health of Gaza Province, Gaza, Mozambique.

*Corresponding author

\section{References}


1. WHO. Epilepsy. https://www.who.int/news-room/fact-sheets/detail/epilepsy. Accessed 10 May 2021.

2. MISAU. 0 projecto piloto em Moçambique encolhe dramàtica a diferença do tratamento da epilepsia. Medical life sciences. 2019. https://www.newsmedical.net/news/20191031/25853/Portuguese.aspx. Acessed 10 May 2021.

3. Manchishi SM. Recent Advances in Antiepileptic Herbal Medicine. Current Neuropharmacology. 2017;16:79-83.

4. Medeiros F, Soares P, De Jesus R, Teixeira D, Alexandre M, et al. Uso medicinal da Cannabis sativa (Cannabaceae) como alternativa no tratamento da epilepsia. Brazilian Journal of Development. 2020; 6(6):41510-41523.

5. Basilio P, Ferreira R. A Importância do uso do Canabidiol em Pacientes com Epilepsia. 2019. Revista Saúde UniToledo. 2019 ; 3(2):86-96.

6. Fard M, Shojaii A. Efficacy of Iranian Traditional Medicine. BioMed Research International. 2013.

7. Adams M, Schneider SV, Kluge M, Kessler M, Hamburger M. (2012). Epilepsy in the Renaissance: Asurvey of remedies from 16th and 17th. Journal of Ethnopharmacology. 2012; 143:1-13.

8. WHO. WHO traditional medicine strategy: 2014-2023. https://www.who.int/publications/i/item/9789241506096. Accessed 10 May 2021.

9. Bandeira S, Gaspar F, Pagula F. African Ethnobotany and Healthcare: Emphasis on Mozambique. Pharmaceutical Biology. 2001; 39:70-73.

10. Goel R, Gawande D, Lagunin A, Randhawa P, Mishra A, Poroikov V. Revealing Medicinal Plants That Are Useful for the Comprehensive Management of Epilepsy and Associated Comorbidities through In Silico Mining of Their Phytochemical Diversity. Planta Med. 2015; 81:495-506.

11. Kaur J, Famta P, Famta M, Mehta M, Satija S, Sharma N, et al. Potential Anti-epileptic Phytoconstituents: An Updated Review. Journal of Ethnopharmacology. 2020.

12. Sahranavard S, Ghafari S, Mosaddegh M. Medicinal plants used in Iranian traditional medicine to treat epilepsy. Seizure. 2014; 23:328-332.

13. Pedersen M, Vestergaard H, Hansen S, Bah S, Diallo D, Jäger A. Pharmacological screening of Malian medicinal plants used against epilepsy. Journal of Ethnopharmacology. 2009; 121:472-475.

14. Bruschi P, Morganti M, Mancini M, Signorini M. Traditional healers and laypeople: A qualitative and quantitative approach to local knowledge on medicinal plants in Muda (Mozambique). Epilepsy \& Behavior. 2011; 128:543-563.

15. IMT. Instituto de Medicina Tradicional (IMT)- Relatorio anual . Ministério da Saude. 2015.

16. INE. IV Censo 2017. http://www.ine.gov.mz/iv-censo-2017. Accessed 20 May 2021.

17. Chinsembu K, Syakalima M, Semenya S. Ethnomedicinal plants used by traditional healers in the management of HIV/AIDS opportunistic diseases in Lusaka, Zambia. South African Journal of Botany. 2018.

18. Chaachouay N, Benkhnigue O, Zidane L. Ethnobotanical Study Aimed at Investigating the Use of Medicinal Plants to Treat Nervous System Diseases in the Rif of Morocco. Journal of Chiropractic Medicine. 2020.

19. Adia M, Anywar G, Byamukama R, Kamatenesi-Mugisha M, Sekagya Y, Kakudidi E, et al. Medicinal plants used in malaria treatment by Prometra herbalists. Journal ofEthnopharmacology. 2014. 155:580-588.

20. Khuankaew S, Srithi K, Tiansawat P, Jampeetong A, Inta A, Wangpakapattanawong P. Ethnobotanical study of medicinal plants used byTai Yai in Northern Thailand. Journal ofEthnopharmacology. 2014. 151:829-838.

21. Mjumbe C, Amuri B, Zeufack L, Kalimira R., Kolela M, Bora B. Knowledge, Attitude and Practice of Traditional Healers on Epilepsy in Lubumbashi. Open Access Library Journal. 2020; 7.

22. Moshi M, Kagashe G, Mbwamboa Z. Plants used to treat epilepsy by Tanzanian traditional healers. Journal of Ethnopharmacology. 2005; 97:327336.

23. Anand P, Othon G, Sakadi F, Tassiou N, Hamani A, Bah A, et al. Epilepsy and traditional healers in the Republic of Guinea: A mixed. Epilepsy \& Behavior. 2019; 92:276-782.

24. Auditeau E, Chassagne F, Bourdy G, Bounlu M, Jost J, Luna J, et al. Herbal medicine for epilepsy seizures in Asia, Africa and Latin America: A. Journal of Ethnopharmacology. 2019; 234:119-153.

25. Barbosa F, Hlashwayo D, Sevastyanov V, Chichava V, Mataveia A, Boane E, et al. Medicinal plants sold for treatment of bacterial and parasitic diseases in humans in Maputo city markets, Mozambique. BMC Complementary Medicine and Therapies. 2020; 20(19).

26. Mongalo N, McGaw L, Segapelo T, Finnie J, Staden V. Ethnobotany, Phytochemistry, Toxicology and Pharmacological properties of Terminalia sericea Burch. ex DC. (Combretaceae)- A review. Journal of Ethnopharmacology. 2016.

27. Tida M, Nanjarisoa O, Rabearivony J, Ranarijaona H, Fenoradosoa T. Ethnobotanical Survey Of Plant Species Used In Traditional Medicine In Bekaraoka Region, Northeastern Madagascar. International Journal of Advanced Research and Publications. 2020; 4(3).

28. Bero J, Ganfon H, Jonville M, Frédérich M, Gbaguidi F, De Mol P, et al. In vitro antiplasmodial activity of plants used in Benin in traditional medicine to treat malaria. Journal of Ethnopharmacology. 2009; 122:430-444.

29. Manuel L, Bechel A, Noormahomed E, Hlashwayo D, Madureira M. Ethnobotanical study of plants used by the traditional healers to treat malaria in Mogovolas district, northern Mozambique. 2020. Heliyon.

30. Conde P, Figueira R, Saraiva S, Catarino L, Romeiras M, Duarte M. A Missão Botânica de Moçambique (1942-1948): Contribuições para o conhecimento da flora medicinal de Moçambique. História, Ciências, Saúde - Manguinhos. 2014; 21(2):539-585.

31. Bruschi P, Morganti M, Mancini M, Signorini M. Traditional healers and laypeople: A qualitative and quantitative approach to local knowledge on medicinal plants in Muda (Mozambique). Journal of Ethnopharmacology. 2011; 128:543-563. 
32. Hoet S, Stevigny C, Herent MF, Quetin-Leclerecq J. Antitrypanosomal Compounds from the Leaf Essential Oil of Stychnos spinosa. Planta Med. 2005; 72:480-482.

33. Anokwuru C, Sigidi M, Boukandou M, Tshisikhawe P, Traore A, Potgieter N. Antioxidant Activity and Spectroscopic Characteristics of Extractable and Non-Extractable Phenolics from Terminalia sericea Burch. ex DC. 23. Molecules. 2018.

34. Tshikalange T, Meyer J, Lall N, Munoz E, Sancho R, Venter M, et al. In vitro anti-HIV-1 properties of e thnobotanically selected South African plants used in the treatment of sexually transmitted diseases. Journal of Ethnopharmacology. 2008; 119:478-481.

35. Fyhrquist, P., Laakso, L., Marco, S., Julkunen-Tiitto, R., \& Hiltunen, R. (2014). Antimycobacterial activity of ellagitannin and ellagic acid derivate rich crude extracts and fractions of five selected species of Terminalia used for treatment of infectious diseases in African traditional medicine. South African Journal of Botany. 2014; 90:1-16.

36. Semenya S, Potgieter M, Erasmus L. Bapedi phytomedicine and their use in the treatment of sexually transmitted infections in Limpopo Province, South Africa. African Journal of Pharmacy and Pharmacology. 2013; 7(6): 250-262.

37. Phumthum M, Balslev H. Thai Ethnomedicinal Plants Used for Diabetes Treatment. OBM Integrative and Complementary Medicine. 2018; 3(3).

38. Sharma J, Gairola S, Gaur R, Painuli R, Siddiqi T. Ethnomedicinal plants used for treating epilepsy by indigenous communities of sub-Himalayan region of Uttarakhand, India. Journal of Ethnopharmacology. 2013; 150:363-370.

39. Cheikhyoussef A, Shapi M, Matengu K, Ashekele H. Ethnobotanical study of indigenous knowledge on medicinal plant use by traditional healers in Oshikoto region, Namibia. Journal of Ethnobiology and Ethnomedicine. 2001; 7(10).

40. Almamy K, Richard W, Franck D, Olivier C, Pierre. Anticonvulsant effects of the Stem bark extract of Annona senegalensis Pers. Molecular \& Clinical Pharmacology. 2012; 3(1):62-72.

41. Igwe S, Nwobodo N. Anticonvulsant Activity of Aqueous Root Extract of Annona Senegalensis Pers. International Journal of Advanced Biological and Biomedical Research. 2014; 2(8):2441-2447.

42. Okoye T, Akah P, Omeje E, Okoye F, Nworu S. Anticonvulsant effect of kaurenoic acid isolated from the root bark of Annona senegalensis. Pharmacology, Biochemistry and Behavior. 2013.

43. Okeye T, Akah $\mathrm{P}$, Omeke $\mathrm{C}$. Evaluation of anticonvulsant and muscle relaxant effects of the methanol root bark extracts of Annona senegalensis. Asian Pacific Journal of Tropical Medicine. 2010; 1:25-28.

44. Okoli C, Onyeto C, Akpa B, Ezike A, Akah P, Okoye T. Neuropharmacological evaluation of Annona senegalensis leaves. African Journal of Biotechnology. 2010; 9(49):8435-8444.

45. Singh V, Jain J, Mishra A. Evaluation of Anticonvulsant and Antioxidant Activity of Senna occidentalis Seeds Extracts. Journal of Drug Delivery and Therapeutics. 2019; 9(2):183-187.

\section{Figures}


Mapa de Enquadramento Geografico da Area de estudo

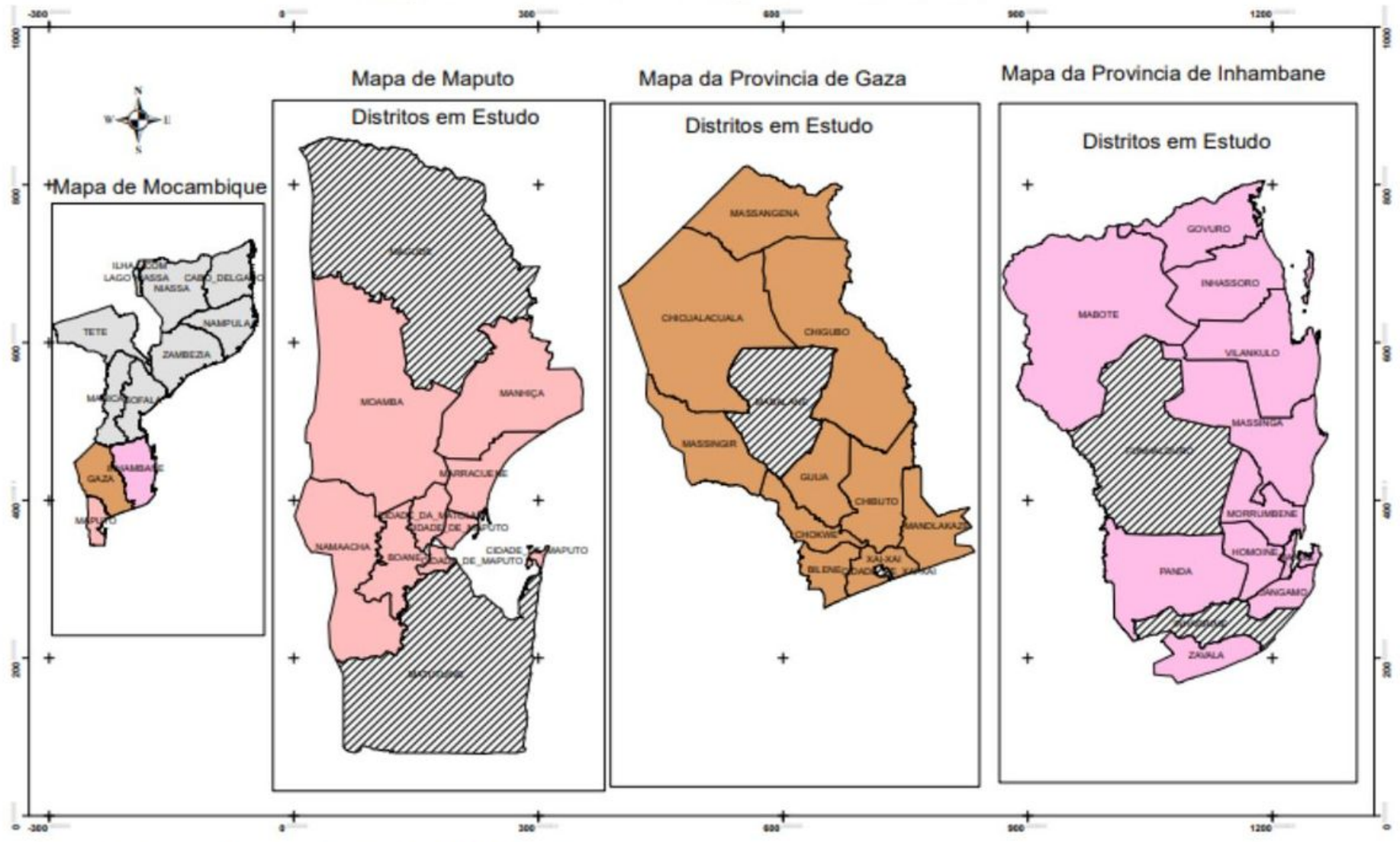

Fonte de Dados Base Simplificada do CENACARTA

Figure 1

Location of the study area. Source: simplified base of the CENACARTA

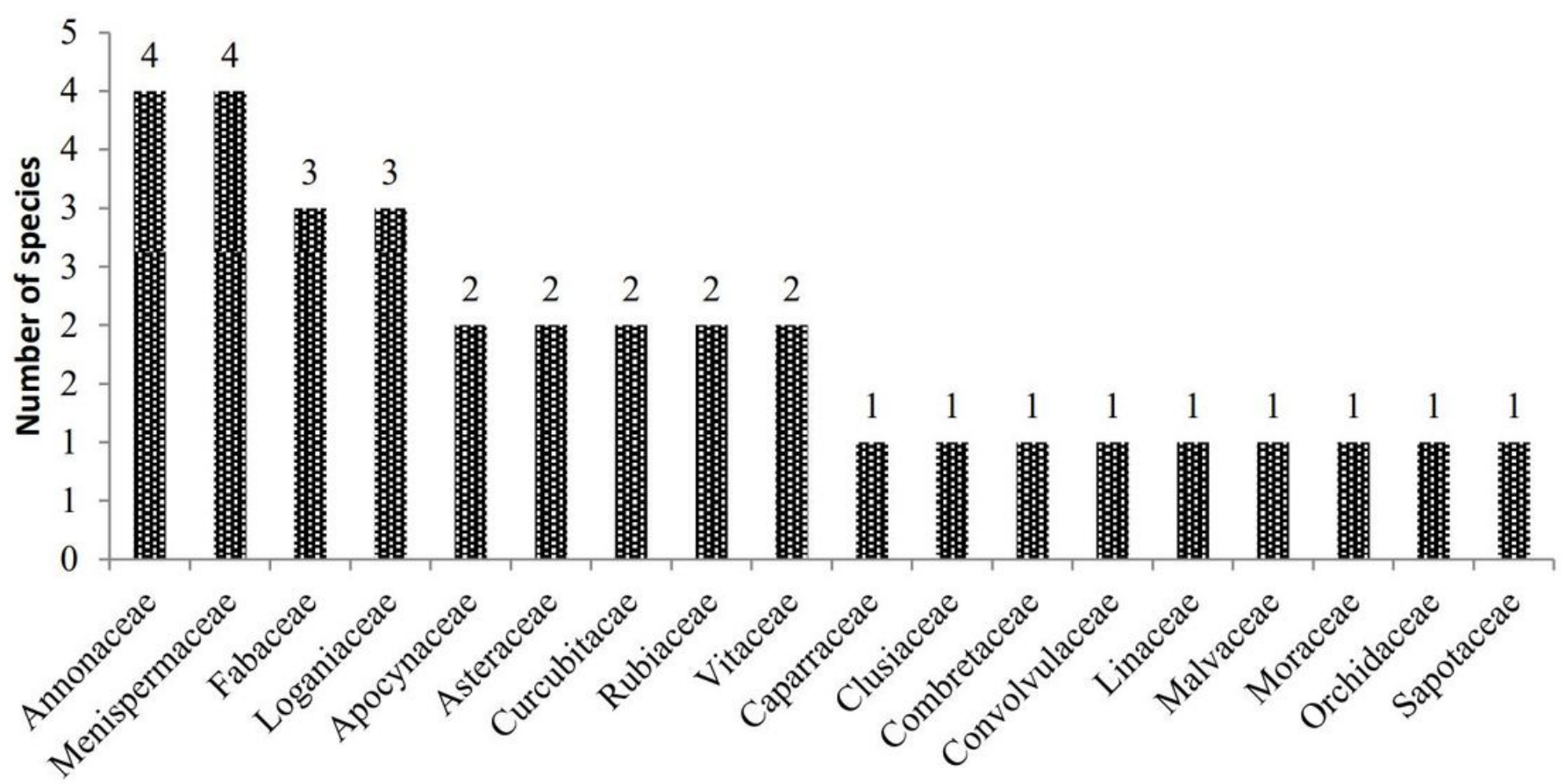


Figure 2

Frequence of botany families

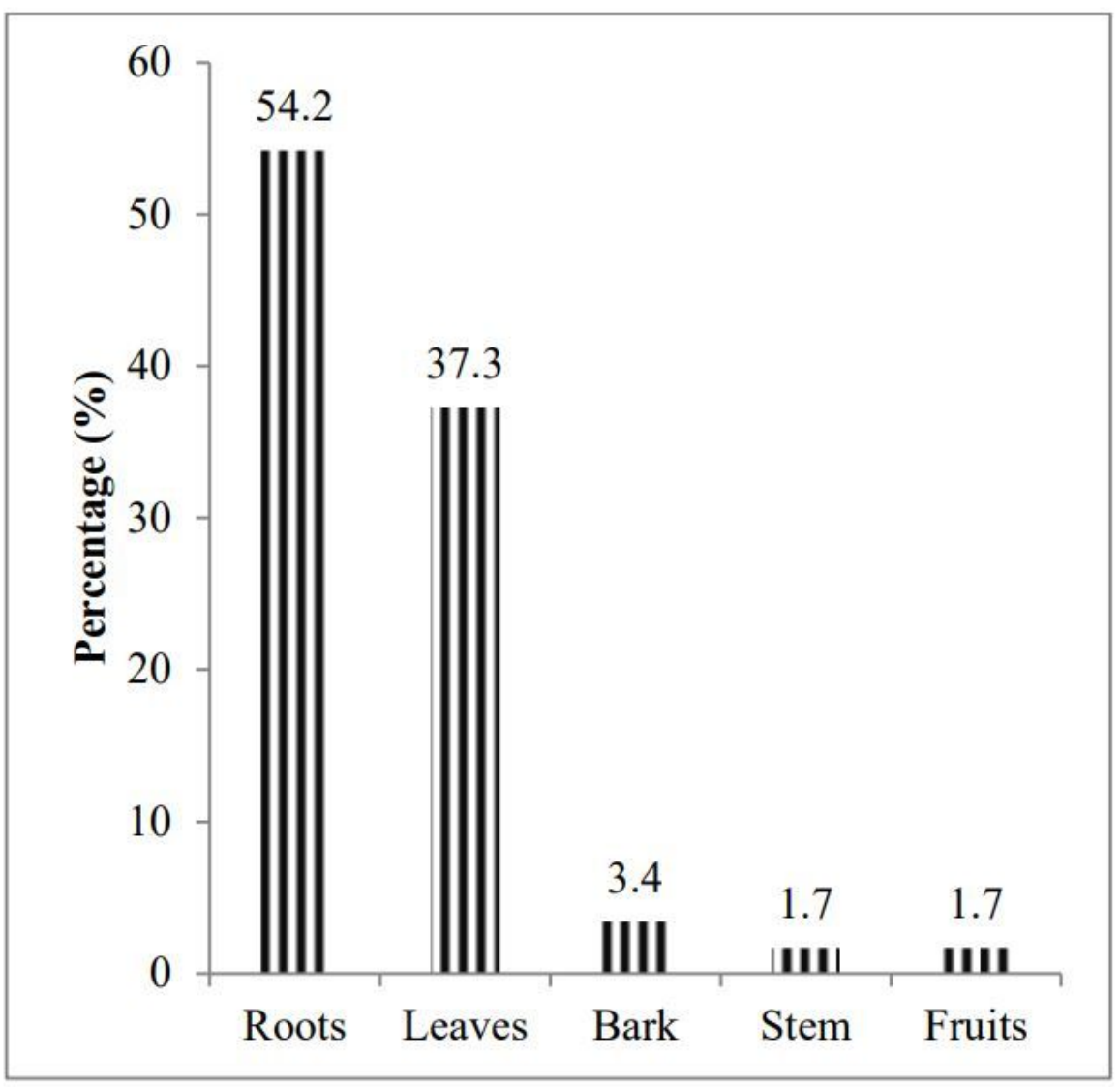

Figure 3

Parts of the plant used for epilepsy treatment

\section{Supplementary Files}

This is a list of supplementary files associated with this preprint. Click to download.

- Aditionalfile1.docx

- aditionalfile2.docx 